\title{
Investigation of the Death Anxiety and Meaning in Life Levels among Middle-Aged Adults
}

\author{
Müge Yukay Yüksel ${ }^{1}$ \\ Marmara University
}

\author{
Ferit Güneş ${ }^{2}$ \\ Ceren $\mathrm{Akdag} \breve{g}^{3}$
}

\begin{abstract}
Life and death constitute a whole, and these concepts become increasingly important in the evaluation of life among middleaged adults. Therefore, this study investigated the correlation between individual levels of death anxiety and meaning in life in terms of certain variables such as gender, age, educational status, marital status, perceived level of devoutness, and witness to death. The sample consisted of 185 individuals (82 males, 103 females; aged 25-55 years) living in Istanbul, Turkey. The data was collected by using a Personal Information Form, the Death Anxiety Scale, and the Meaning in Life Questionnaire. The findings showed that, as the death anxiety and meaning in life subscale levels increased, the meaning in life levels decreased. In addition, it was found that death anxiety does not differ according to the following variables: age (25-35 and 35-55 years), educational status, marital status, perceived religious belief, and living with someone. The results also indicated that women tend to experience more death anxiety than men, and that individuals who witnessed the death of a close person generally feel more death anxiety than those who did not.
\end{abstract}

\section{Keywords}

Death $\bullet$ Death anxiety $\bullet$ Meaning in life $\bullet$ Adulthood

\section{Yetişkinlerin Ölüm Kaygısı ve Yaşamı Anlamlandırma Düzeylerinin İncelenmesi}

$\mathrm{O} z$

Yaşam ve ölüm bir bütünü oluşturmakta, orta yetişkinliğe doğru ilerleyen yıllarda geçirilen ömrün değerlendirme sürecinde bu kavramlar daha fazla önem kazanmaktadır. Bu nedenle, bu araştırmada, bireylerin ölüm kaygı düzeyleri ile yaşam anlamı arasındaki ilişkinin çeșitli değișkenler (cinsiyet, yaş, eğitim durumu, medeni durum, kiminle yaşadığı, algılanan dindarlık düzeyi, ölüme tanık olma) açısından incelenmesi amaçlanmıștır. Örneklem grubu İstanbul'da yaşayan 25-55 yaș arası 185 (82 erkek, 103 kadın) bireyden oluşmaktadır. Araştırmada Kişisel Bilgi Formu, Ölüm Kaygısı Ölçeği ile Yaşamın Anlamı Ölçeği kullanılarak veriler toplanmış ve sonuçlar değerlendirilmiştir. Araştırmadan elde edilen bulgulara göre, yetişkinlik dönemindeki bireylerin ölüm kaygısı düzeyleri arttıkça yaşam anlamı düzeylerinde azalma olduğu, yaşam anlamı alt boyutu olan aranan anlam düzeylerinde de artış olduğu belirlenmiștir. Araștırmanın bağımsız değişkenlerinin ölüm kaygısı puanlarıyla yapılan analizleri sonucunda elde edilen bulgulara göre; ölüm kaygısının yaşa (25-35 yaș, 35-55 yaș), eğitim durumuna, medeni durumuna, algılanan dini inanç düzeyine ve bireyin yalnız yaşayıp yaşamamasına göre farklılaşmadığı tespit edilmiștir. Bununla beraber, kadınların erkeklerden daha fazla ölüm kaygısı yaşadığı ve yakın birinin ölümüne tanık olan bireylerde daha yoğun ölüm kaygısı yaşandığı tespit edilmiştir.

\section{Anahtar Kelimeler}

Ölüm • Ölüm kaygısı • Yaşamın anlamı • Yetişkinlik

1 Correspondance to: Department of Educational Sciences, Marmara University, Goztepe Campus, Kadikoy 34722 , Istanbul, Turkey. Email:muge.yuksel@marmara.edu.tr

2 Psychological Counselor. Email: gunesferit@hotmail.com

3 Psychological Counselor. Email:cerenakdag@windowslive.com

Citation: Yukay Yüksel, M., Güneş, F., \& Akdağ, C. (2017). Investigation of the death anxiety and meaning in life levels among middle-aged adults. Spiritual Psychology and Counseling, 2, 165-181. http://dx.doi.org/10.12738/spc.2017.2.0024 
The years from young to middle adulthood is considered as a period in which one's life is evaluated, previous experiences are given a meaning, and more realistic plans are made for the future. Although the thought of life coming to an end is not at the forefront, death anxiety tends to emerge among certain individuals in this time period. For some, death means that life will end and various hopes and desires will remain unfulfilled.

The phenomenon of death has been dealt with in many psychological theories, especially in the context of the evaluation and meaning of life, and it has played an important role in the process of understanding and evaluating humans in general. In regard to the inner drive that guides human behaviors, Sigmund Freud mentioned two basic instincts: the death instinct, which expresses destructive thoughts; and the life instinct, which represents the continuity of life. By expressing that the purpose of life is death, Freud considered that, in every human being, there is the desire to die without consciousness (Geçtan, 2005). Death anxiety is one of the most important concerns of the upper self, and such anxiety is thought to play an effective role in psychopathology and psychosomatic diseases (Freud, 1992). Carl Jung, on the other hand, suggested that, since the fear of life underlies the anxiety of death, one who fears death is actually afraid of life (Jung, 1997). In general, existentialist philosophers and psychologists have argued that death anxiety is an inevitable anxiety that exists in the depths of individual egos, without reaching the conscious level (Geçtan, 1990). Yalom (2001) argued that the inevitable is not death anxiety, but death itself. He also pointed out that, in order to deal with death anxiety, one must face death, recognize death, and understand death (Yalom, 2001). According to existentialists, every inner life must ultimately come to terms with the finiteness of life and confront the question of "What is the meaning of life?" According to Tanhan (2007), the way in which an individual is able to remove such anxiety is that he/she lives in the presence of death and discovers the meaning of life.

Meaning refers to a network of connections, implications, and translations that help us become more aware of our existence in the world. Meaning also makes us feel that our lives are important and our existence is not simply based on seconds, days, months, and years (Akın \& Taş, 2015). Although there are many different concepts, according to some viewpoints, life and death constitute a whole. As Kalaoğlu Öztürk (2010) indicated, death is the aim of life and it completes life. Meanwhile, death anxiety has been defined as a multidimensional concept. The most emphasized aspects have included: fear of uncertainty and loneliness; fear of losing one's relatives; fear of losing one's identity; fear of punishment after death; worry about the ones left behind; fear of losing control; fear of suffering; loss of body; and fear of extinction (Karaca, 2000). Ünver (1938) found that the Turkish people do not fear death and they have accepted that death is inevitable. However, other studies have shown that the meaning of death for adults can differ from that of children and adolescents. In addition, various concepts, such as one's culture, belief system, and lifestyle, can affect an individual's feelings about death (Sezer \& Saya, 2009). 
According to Levinson (1986), the period from ages 17 to 45 is referred to as the "first period of adulthood." This is a time when life satisfaction is generally high in terms of sexuality, love, family life, professional progression, and creativity, despite certain contradictions such as stress, risk, and frustration (Levinson, 1986; Havighurst, 1972) as well as unfulfilled desires and expectations. Middle adulthood is in the 40-65 age range; that is, between middle and advanced age. In this period, a biological pause and regression can occur for an individual, while he/she continues a psychologically satisfying life.

By their late 30s and early 40s, most individuals generally realize their dreams in life and ideally find a balance between work and life (Erikson, 1984; Onur, 2000; Levinson, 1986). Together with the search for the meaning in life, feelings, and thoughts about death can emerge during this period. Numerous studies have focused on the variables of death anxiety and the meaning in life among young adults. Galt and Hayslip (1998) reported that the anxiety levels of the elderly were higher than those among younger adults. More specifically, they compared 46 individuals (aged 17-25 years) with 40 individuals (aged 60 and older), and found that the levels of death anxiety among the latter were higher than those of the former. Şenol (1989) found that the anxiety and fear levels of the elderly were generally in the middle range, while the levels of death anxiety showed differences according to age group. In this regard, the highest levels of death anxiety were observed in the 60-64 age range, with lower levels found among those aged 70 and older. Reker and Fry (2003) investigated the meaning of life levels among 163 young adults (mean age of 21) and 144 older adults (a mean age of 70), and found that there was no significant difference between the two age groups. Yüksel (2013) examined the relationship between the meaning of life and independent variables among young adults, and found that the meaning of life does not differ in terms of gender, perceived socio-economic level, and parental togetherness (or separation). However, the meaning of life among young adults can significantly differ in terms of perceived parental attitude and position in birth order. Finally, Taş (2011) found that, although there was no significant difference between male and female teachers and their respective ages, the former generally performed more meaning of life searches than their female counterparts.

From young adulthood and on, the perceptions of human life and the search for meaning can change along life's responsibilities. In addition, the meaning attributed to events in life can change in the context of one's personality, previous experiences, and the ability to accept and cope with certain problems. By the end of this period, men tend to take a pause, while women generally focus on family, work, and friendships. Regardless of gender, it is necessary to establish a stable and integrated life structure in which the individual learns more about his/her role in society and acts accordingly. According to Levinson (1996), by managing a family and fulfilling 
social responsibilities, one can enjoy life. However, certain problems encountered during young adulthood may be more difficult to deal with in middle adulthood, due to the changing roles, life responsibilities, and burdens. Previous studies have shown that, the moral and material burdens of older adults, including the loss of close family members and friends, and the onset of andropause or menopause, may cause one to question the meaning of life and experience death anxiety (Blazer, 1973; Combs, 1981; Ka-Ying Hui \& Fung, 2008; Martindale, 1998; Prager, 1997; Rappaport, Fossler, Bross, \& Gilden, 1993; Russac, Gatliff, Reece, \& Spootswood, 2007).

Successful young and middle-aged adults appear to be more loving, tolerant, and mature, while maintaining a life that is free from internal conflicts. In contrast, those that fail to achieve such aspects tend to see life as difficult, unpleasant, and pointless (Levinson, 1996; Erikson, 1984). Thus, it is important to evaluate this period of adulthood by considering various cultures and characteristics among different age groups. In practice, it is believed that experts in the field of mental health generally provide psychological help for adults, especially in the context of protective and preventive mental health functions. Based on this perspective, the purpose of the present study is to investigate the correlation between individual levels of death anxiety and meaning in life in terms of certain variables such as gender, age, educational status, marital status, perceived level of devoutness, and witness to death. In addition, the research questions are presented as follows:

(i) Do the death anxiety scores of individuals in adulthood significantly predict their meaning in life scores?

(ii) Do the meaning in life scores of individuals in adulthood differ in terms of age, gender, marital status, educational status, living with someone, perceived level of devoutness, and witness to death?

(iii) Do the death anxiety scores of individuals in adulthood differ in terms of age, gender, marital status, educational status, living with someone, perceived level of devoutness, and witness to death?

\section{Method}

\section{Research Model}

This study investigated the relationship between the levels of death anxiety and meaning in life among a sample of individuals (aged 25 and older) living in Istanbul, Turkey. For this purpose, the correlational survey model, which aims to determine the existence and/or the degree of change between two or more variables (Balc1, 2005; Karasar, 2012), was applied. 


\section{Sample}

The participants in this study, selected through random sampling, consisted of 185 individuals (82 males and 103 females; aged 25-55 years, $\bar{X}=32.08, S D=$ 8.66) living in Istanbul during the 2015-2016 academic year. In regard to age, 47 $(57.3 \%)$ males were aged $25-35$ years, with 35 (42.7\%) over 35 years of age, while $73(70.9 \%)$ females were aged 25-35 years, with $30(29.1 \%)$ aged 35-55 years. Regarding educational status, 52 (28\%) had "no university degree," 99 (54\%) had an "undergraduate degree," and $34(18 \%)$ had a "graduate degree." Concerning marital status, 86 (46\%) were "single," while 99 (54\%) were "married." However, 69 (37\%) of them lived "alone," while 116 (63\%) lived "with family." According to the data from the Personal Information Form, 36 (19\%) were "devout," 49 (26\%) were "somewhat devout," 30 (16\%) were "hesitant," 59 (32\%) were "pretty devout," and $11(6 \%)$ were "very devout." Finally, 73 (39\%) stated that they had witnessed death, while $112(61 \%)$ did not witness death in the past.

\section{Data Collection Tools}

In this study, the "Meaning in Life Scale" was used to determine the meaning in life levels among the individuals, while the "Death Anxiety Scale" was used to determine the levels of death anxiety. The Personal Information Form was prepared by the researcher and it was used to obtain demographic information about the individuals. The details regarding the data collection tools are as follows.

Death Anxiety Scale (DAS): This scale was developed by Templer in 1970 and it consists of 15 yes or no questions, with a maximum of 15 points. For example, if the first nine questions are marked as "YES" and the last six questions are marked as "NO," then the participant receives 1 point for each item, after which the high score indicates that there is a high level of death anxiety. The scale consists of statements that express feelings of anxiety, fear, and horror in relation to death. The reliability and validity of the Turkish version of the DAS was measured by face validity and the test-retest method with a sample of university students. Since the reliability coefficient of the scale was $r=.86(p<.001)$, it can be stated that this version of the DAS is compatible with the original scale and that it is a valid tool for determining the level of death anxiety (Şenol, 1989).

The Meaning in Life Questionnaire (MLQ): This scale, developed by Steger, Frazier, Oishi, and Kaler (2006), assesses individuals' understanding of the meaning in life. This scale was previously used by researchers in Turkey to assess the psychometric properties of individuals among various age groups (Sezer, 2012). It consists of 10 expressions about the meaning in life, based on a 7-point Likert scale ranging from "Absolutely Wrong” to "Absolutely Right." Overall, there are nine positive items $(1,2$, $3,4,5,6,7,8$, and 10) and one negative item (9). The scale consists of two subscales as 
presence of meaning (items 1, 4, 5, 6, 9) and search for meaning (items 2, 3, 7, 8, 10). The range of scores varies from 7 to 70 . High scores from subscales of the scale indicate that the individual possesses a high level of specificity for that subscale. Steger et al. (2006) found that the internal consistency reliability coefficient of the MLQ was .82 for the presence of meaning subscale, and .87 for the search for meaning subscale. After four weeks, they found the reliability coefficients for the same subscales respectively as.70 and .73 (Demirdağ \& Kalafat, 2015). In a similar scale validation study, correlations between the MLQ and the Originality Scale were measured and it was found that the meaning in life was positively related to originality. These correlations are an important evidence for the convergent validity of the scale (Akın \& Taş, 2015).

Personal Information Form; It was prepared by the researchers with the help of expert opinions in order to collect data on the independent variables of the research. In this form, some answers were search for for questions such as age, gender, educational status, marital status, perceived religious belief level, witness to death of the individuals that constitutes the sample group of the research.

\section{Data analysis}

The Kolmogorov Smirnov test was used to determine the normal distribution of the data that obtained from for statistical analysis. The data was analyzed by using the SPSS 16.0 statistical program, after which Pearson's correlation coefficient, the independent group t-test, and the analysis of variance (ANOVA) were employed.

\section{Findings}

This section discusses the findings in relation to the three aforementioned research questions. The findings of the first research question ("Do the death anxiety scores individuals in adulthood significantly predict their meaning in life scores?") are presented in Tables 1 and 2 .

Table 1

Results of the Kolmogorov-Smirnov Test for Controlling the Normal Distribution of the DAS, Meaning of Life, and Subscale Scores

\begin{tabular}{lcccccc}
\hline & $\mathrm{X}_{\min }$ & $\mathrm{X}_{\max }$ & $\bar{X}$ & $\mathrm{X}_{\text {Std.Dev. }}$ & Skewness & Kurtosis \\
\hline Death Anxiety Scale & 1 & 15 & 8.03 & 3.01 & -0.02 & -0.56 \\
Presence of Meaning & 5 & 35 & 26.85 & 6.30 & -0.88 & 0.49 \\
Search for Meaning & 5 & 35 & 23.00 & 8.06 & -0.64 & -0.30 \\
Meaning in Life Total & 14 & 70 & 49.75 & 10.66 & $-0,46$ & 0,38 \\
\hline
\end{tabular}

As shown in Table 1, as a result of one sample Kolmogorov-Smirnov analysis which was used to determine whether the distribution of the death anxiety scale and meaning in life scale scores of the individuals constituting the sample group was significant, there found to be a significant difference $(p<, 05)$. 
Table 2

Pearson Analysis Results for Determining the Correlation Between the scores of Death Anxiety and Meaning in Life \& its subscales

\begin{tabular}{lc}
\hline & Death Anxiety Scale \\
\hline Presence of Meaning & $-0,062$ \\
Search for Meaning & 0,003 \\
Meaning in Life Total & $-0,031^{*}$ \\
\hline${ }^{*} p<.05$ &
\end{tabular}

As shown in Table 2, Pearson Product Moment Correlations were computed in order to determine whether there was a significant relationship between the scores of death anxiety scale and the meaning in life scale scores of the individuals constituting the sample group. It was found that there was a negative correlation between the meaning in life and death anxiety $(p<, 05)$. In these premises, as the death anxiety increases, the meaning in life decreases. On the other hand death anxiety was found non-significantly related to presence of meaning and search for meaning.

Table 3

Simple linear regression analysis results related to Adults'Death Anxiety Scale Scores based on Meaning in Life

\begin{tabular}{lcccccc}
\hline Score & $\beta$ & $t$ & $p$ & $\mathrm{R}^{2}$ & $\mathrm{~F}$ & $p$ \\
\hline Regression Coefficient & 8,46 & $7, .97$ & .000 & \multirow{2}{*}{.001} & .172 & .678 \\
Meaning in Life & -.009 & -.42 & .678 & & & \\
\hline
\end{tabular}

As shown in Table 3, death anxiety is the dependent variable, while the meaning in life is the independent variable. The independent variable explains approximately $0.1 \%$ of the change in the dependent variable $\left(\mathrm{R}^{2}=.001\right)$. In addition, the linear regression model used for the dependent variable and the independent variable was not statistically significant $(\mathrm{F}=.172, p>.05)$, and there was no predictive power in the meaning in life variable on the death anxiety variable $(\mathrm{t}=-.42 p>.05)$.

According to Table 4, the difference between the presence of meaning subscale and variables, such as marital status and living with someone, was significant $(t=-2.30$, $p<0.05 ; t=-3.34, p<0.01)$. In other words, it was determined that individuals who are married and living with their family have higher satisfaction from their current lifestyles. However, the difference between the meaning in life, the subscale of the presence of meaning, and the witness to death was significant $(t=2.00, p<0.05$; $t=2.95, p<0.05)$; that is, individuals who witness death are more satisfied with their lives. However, there was no significant difference between the meaning in life subscales in terms of age and gender $(p>.05)$. 
Table 4

Results of the Independent Group T-Test on the Meaning in Life and Subscale Scores in terms of Age, Gender, Marital Status, Living with Someone, and Witness to Death

\begin{tabular}{|c|c|c|c|c|c|c|c|}
\hline & $\mathrm{N}$ & & $\mathrm{X}$ & sd. & $t$ & df. & $p$ \\
\hline \multicolumn{8}{|c|}{ Age Groups } \\
\hline \multirow[t]{2}{*}{ Presence of Meaning } & 120 & $25-35$ & 26.43 & 6.45 & -1.245 & 183 & 0.215 \\
\hline & 65 & $35-55$ & 27.63 & 5.98 & & & \\
\hline \multirow[t]{2}{*}{ Search for Meaning } & 120 & $25-35$ & 23.48 & 7.67 & 1.109 & 183 & 0.269 \\
\hline & 65 & $35-55$ & 22.11 & 8.73 & & & \\
\hline \multirow[t]{2}{*}{ Meaning in Life Total } & 120 & $25-35$ & 49.75 & 10.17 & 0.007 & 183 & 0.994 \\
\hline & 65 & $35-55$ & 49.74 & 11.60 & & & \\
\hline \multirow{3}{*}{ Presence of Meaning } & & Gender & & & & & \\
\hline & 82 & Male & 27.15 & 6.78 & 0.573 & 183 & 0.568 \\
\hline & 103 & Female & 26.61 & 5.91 & & & \\
\hline \multirow[t]{2}{*}{ Search for Meaning } & 82 & Male & 23.10 & 8.78 & 0.146 & 183 & 0.884 \\
\hline & 103 & Female & 22.92 & 7.48 & & & \\
\hline \multirow[t]{2}{*}{ Meaning in Life Total } & 82 & Male & 50.24 & 11.68 & 0.566 & 183 & 0.572 \\
\hline & 103 & Female & 49.35 & 9.82 & & & \\
\hline \multirow{3}{*}{ Presence of Meaning } & & Marital Status & & & & & \\
\hline & 86 & Single & 25.72 & 6.54 & -2.297 & 183 & $0.023 *$ \\
\hline & 99 & Married & 27.83 & 5.94 & & & \\
\hline \multirow[t]{2}{*}{ Search for Meaning } & 86 & Single & 24.16 & 7.62 & 1.840 & 183 & 0.067 \\
\hline & 99 & Married & 21.99 & 8.33 & & & \\
\hline \multirow[t]{2}{*}{ Meaning in Life Total } & 86 & Single & 49.78 & 10.34 & 0.039 & 183 & 0.969 \\
\hline & 99 & Married & 49.72 & 10.99 & & & \\
\hline \multirow{4}{*}{ Presence of Meaning } & & Living with & & & & & \\
\hline & & Someone & & & & & \\
\hline & 69 & Alone & 24.90 & 6.83 & -3.337 & 183 & $0.001 * *$ \\
\hline & 116 & With family & 28.01 & 5.68 & & & \\
\hline \multirow[t]{2}{*}{ Search for Meaning } & 69 & Alone & 23.74 & 8.16 & 0.962 & 183 & 0.338 \\
\hline & 116 & With family & 22.56 & 8.01 & & & \\
\hline \multirow[t]{2}{*}{ Meaning in Life Total } & 69 & Alone & 48.64 & 11.01 & -1.091 & 183 & 0.277 \\
\hline & 116 & With family & 50.41 & 10.44 & & & \\
\hline \multirow{4}{*}{ Presence of Meaning } & & Witness to & & & & & \\
\hline & & Death & & & & & \\
\hline & 73 & Yes & 28.51 & 5.76 & 2.952 & 183 & $0.004 * *$ \\
\hline & 112 & No & 25.77 & 6.42 & & & \\
\hline \multirow[t]{2}{*}{ Search for Meaning } & 73 & Yes & 23.29 & 8.59 & 0.391 & 183 & 0.696 \\
\hline & 112 & No & 22.81 & 7.73 & & & \\
\hline \multirow[t]{2}{*}{ Meaning in Life Total } & 73 & Yes & 51.67 & 10.10 & 1.999 & 183 & $0.047 *$ \\
\hline & 112 & No & 48.49 & 10.88 & & & \\
\hline
\end{tabular}

$* p<.05 ; * * p<.01$

Table 5

ANOVA Results for Identifying whether the Meaning in Life and its Subscales Differ depending on Educational Status

\begin{tabular}{llcccccccc}
\hline & & $\begin{array}{c}\text { Sum of } \\
\text { squares }\end{array}$ & df. & $\begin{array}{c}\text { Mean } \\
\text { square }\end{array}$ & F & $p$ & & $\bar{X}$ & Sd. \\
\hline \multirow{2}{*}{$\begin{array}{l}\text { Presence of } \\
\text { Meaning }\end{array}$} & Between groups & 88.11 & 2 & 44.05 & 1.112 & 0.331 & No university & 25.81 & 7.09 \\
& Within groups & 7207.66 & 182 & 39.60 & & & Undergraduate & 27.41 & 5.37 \\
& Total & 7295.76 & 184 & & & & Graduate & 26.79 & 7.43 \\
\hline \multirow{2}{*}{$\begin{array}{l}\text { Search for } \\
\text { Meaning }\end{array}$} & Between groups & 209.96 & 2 & 104.98 & 1.626 & 0.200 & No university & 21.58 & 8.68 \\
& Within groups & 11750.04 & 182 & 64.56 & & & Undergraduate & 23.15 & 8.01 \\
& Total & 11960.00 & 184 & & & & Graduate & 24.74 & 7.02 \\
Meaning in & Between groups & 484.04 & 2 & 242.02 & 2.156 & 0.119 & No university & 47.19 & 12.50 \\
Life Total & Within groups & 20435.02 & 182 & 112.28 & & & Undergraduate & 50.57 & 9.86 \\
& Total & 20919.06 & 184 & & & & Graduate & 51.26 & 9.43 \\
\hline
\end{tabular}


According to Table 5, there was no significant difference between the meaning in life and its subscale scores, as a result of the ANOVA $(p>.05)$.

The findings of the third research question ("Do the death anxiety scores of individuals in adulthood differ in terms of age, gender, marital status, educational status, living with someone, perceived level of devoutness, and witness to death?') are presented in Tables 6,7 , and 8 .

Table 6

Results for Identifying Whether the Meaning in Life and its Subscales Differ depending on the Perceived Level of Devoutness

\begin{tabular}{|c|c|c|c|c|c|c|c|}
\hline & $\mathrm{N}$ & Groups & $N$ & $\overline{\mathrm{X}}$ & $x^{2}$ & $\mathrm{df}$ & $p$ \\
\hline \multirow{6}{*}{ Presence of Meaning } & 36 & Not devout & 36 & 63.29 & \multirow{6}{*}{27.589} & \multirow{6}{*}{4} & \multirow{6}{*}{$0.001 * *$} \\
\hline & 49 & Somewhat devout & 49 & 79.41 & & & \\
\hline & 30 & Hesitant & 30 & 97.17 & & & \\
\hline & 59 & Pretty devout & 59 & 115.00 & & & \\
\hline & 11 & Very devout & 11 & 121.41 & & & \\
\hline & 185 & Total & 185 & & & & \\
\hline \multirow{6}{*}{ Search for Meaning } & 36 & Not devout & 36 & 88.14 & \multirow{6}{*}{7.164} & \multirow{6}{*}{4} & \multirow{6}{*}{0.127} \\
\hline & 49 & Somewhat devout & 49 & 89.91 & & & \\
\hline & 30 & Hesitant & 30 & 83.17 & & & \\
\hline & 59 & Pretty devout & 59 & 96.53 & & & \\
\hline & 11 & Very devout & 11 & 130.59 & & & \\
\hline & 185 & Total & 185 & & & & \\
\hline \multirow{6}{*}{ Meaning in Life Total } & 36 & Not devout & 36 & 71.85 & \multirow{6}{*}{17.872} & \multirow{6}{*}{4} & \multirow{6}{*}{$0.001 * *$} \\
\hline & 49 & Somewhat devout & 49 & 84.49 & & & \\
\hline & 30 & Hesitant & 30 & 88.68 & & & \\
\hline & 59 & Pretty devout & 59 & 107.52 & & & \\
\hline & 11 & Very devout & 11 & 134.05 & & & \\
\hline & 185 & Total & 185 & & & & \\
\hline
\end{tabular}

$* * p<.01$

According to Table 6, there was a significant difference between the meaning in life and its subscale scores in terms of the perceived level of devoutness, as a result of the Kruskal-Wallis H Test $\left(x^{2}=27.589 ; p<.01 ; x^{2}=17.872 ; p<.01\right)$. In addition, the mean scores of the perceived level of devoutness differed in regard to the levels of "pretty devout" and "very devout," whereas the scores were closer to one another in relation to other levels. 
Table 7

Death Anxiety and the Results of the Independent Group T-Test in Terms of the Age, Gender, Marital Status, Educational Status, Living with Someone, Perceived Level of Devoutness, and Witness to Death

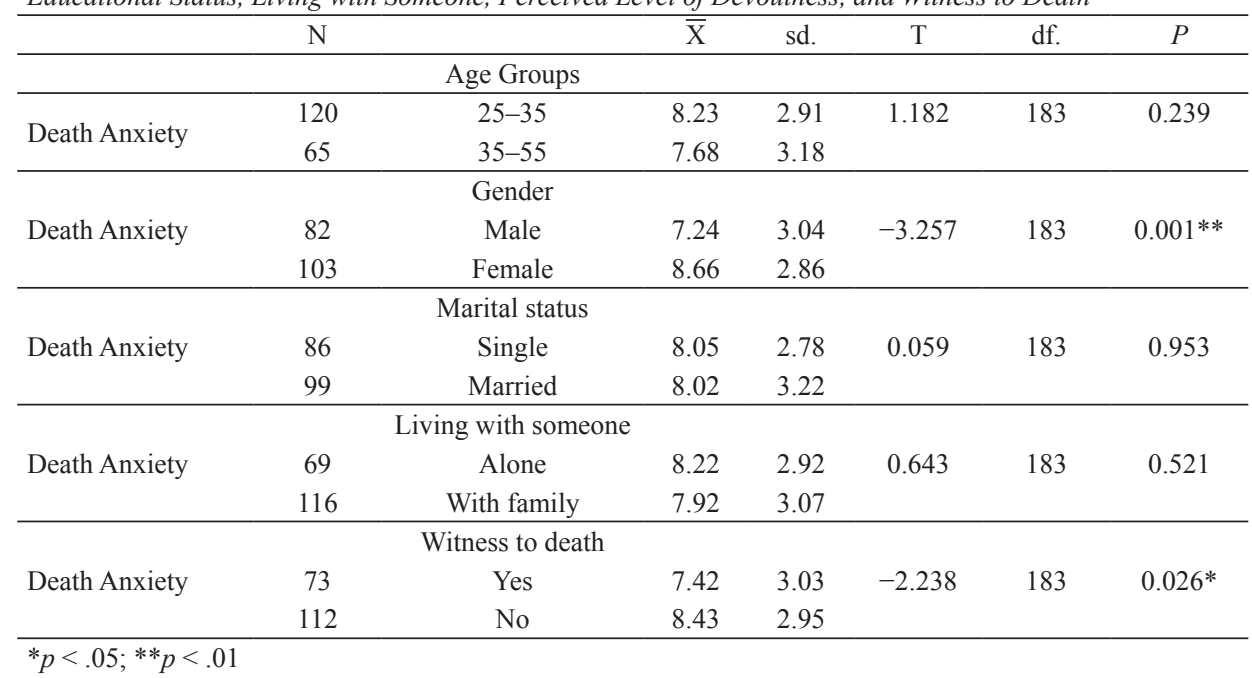

According to Table 7, there was a significant difference between the death anxiety scores and gender, particularly among the females in the sample $(t=-3.26: p<0.01)$. In other words, the level of death anxiety among the females was greater than that among the males. Moreover, the difference between the death anxiety and witness to death variables was also significant $(t=-2.24: p<0.05)$; that is, the level of death anxiety was higher among those who did not witness death.

Table 8

Results of the ANOVA for Identifying Whether the Death Anxiety Scores Differ depending on Education Level

\begin{tabular}{|c|c|c|c|c|c|c|c|c|c|}
\hline & & $\begin{array}{l}\text { Sum of } \\
\text { squares }\end{array}$ & df. & $\begin{array}{l}\text { Mean } \\
\text { square }\end{array}$ & $\mathrm{F}$ & $p$ & & $\bar{X}$ & Sd. \\
\hline \multirow{3}{*}{$\begin{array}{l}\text { Death } \\
\text { Anxiety } \\
\text { Scores }\end{array}$} & $\begin{array}{l}\text { Between } \\
\text { groups }\end{array}$ & 11.92 & 2 & 5.96 & \multirow[t]{3}{*}{0.653} & \multirow[t]{3}{*}{0,522} & No university & 8.12 & 3.33 \\
\hline & Within groups & 1659.89 & 182 & \multirow[t]{2}{*}{9.12} & & & Undergraduate & 8.17 & 3.01 \\
\hline & Total & 1671.81 & 184 & & & & Graduate & 7.50 & 2.50 \\
\hline
\end{tabular}

As shown in Table 8, there was no significant difference between education level and the death anxiety scores, as a result of the ANOVA $(p>.05)$.

Table 9

Results of the Kruskal-Wallis H Test for Identifying Whether Death Anxiety Scores Differ depending on the Perceived Level of Devoutness

\begin{tabular}{llccccc}
\hline Scores & Groups & $N$ & $\bar{X}_{\text {sira }}$ & $x^{2}$ & $s d$ & $p$ \\
\hline \multirow{5}{*}{ Death Anxiety } & Not devout & 36 & 97.86 & & & \\
& Somewhat devout & 49 & 84.52 & & & \\
& Hesitant & 30 & 102.10 & & & \\
& Pretty devout & 59 & 91.04 & 2.718 & & \\
& Very devout & 11 & 100.55 & & \\
& Total & 185 & & & \\
\hline
\end{tabular}


As shown in Table 9, there was no significant difference between the perceived level of devoutness and the death anxiety scores, as a result of the Kruskal-Wallis $\mathrm{H}$ Test $\left(x^{2}=2.718 ; p>, 05\right)$.

\section{Discussion}

This study investigated the levels of death anxiety and meaning in life among a sample of middle-aged adults. It also determined whether there was a correlation between death anxiety and the meaning in life in terms of variables such as age, gender, marital status, educational status, living with someone, perceived level of devoutness, and witness to death. The results showed that, as the death anxiety and meaning in life subscale levels increased, the meaning in life levels decreased. This also supports the idea that individuals begin to examine the meaning in life, as a result of facing the idea of death (Geçtan, 2005; Sigrist, 2015). The results of previous studies are in accordance with this finding. Lyke (2013) examined the correlation between the meaning in life and the fear of death among 168 young adults, and found that only the search for the meaning in life was significantly related to the fear of death. Routledge and Juhl (2010) revealed that, among a group of 60 psychology students, those with high death anxiety were the weakest in terms of searching for the meaning in life. In their study of 26 metaphorical perceptions of death, Ross and Pollio (1991) determined that those who had negative metaphors related to death had difficulty searching for the meaning in life, while those who had positive metaphors about death enriched their search for such meaning by making more diverse transformations in their lives. According to the study's independent variables, death anxiety did not differ in terms of age (25-35 years, and 35 years and older), educational status, marital status, perceived level of devoutness, and whether the individual lived alone. However, it was found that women had greater death anxiety than men, and those who witnessed the death of a close relative had greater death anxiety in general.

Previous studies also indicated that the level of death anxiety did not differ in terms of age (Hökelekli, 1991; Kasar, Karaman, Şahin, Y1ldırım, \& Aykar, 2016; Y1ld1z, 1998). Contrary to these findings, Thorson and Powell (1988) and Henrie and Hicks-Patrick (1970) found that the elderly experienced less death anxiety than younger individuals, since their conflict-resolving and anxiety-coping skills were better. Russac, Gatliff, Reece, and Spootswood (2007) investigated the relationship between death anxiety and the variables of age and gender in their study of 304 individuals (aged 18-87 years) living in the United States. They found that the level of death anxiety in both males and females diminished after 20 years of age. However, the level of death anxiety among females reappeared in their 50s. In order to test these findings, they administered the DAS to 113 females between the ages of 18 and 85 . The findings indicated that hormonal changes, such as menopause, directly affected 
the mental experiences and the level of death anxiety among older females. Since the sample in the present study consisted of individuals 25-35 years of age, this can explain why there was no difference between the death anxiety scores and age.

However, it was determined that education level, marital status, living with someone or living alone, and perceived level of devoutness did not differ in terms of death anxiety. Similarly, Cole (1979) found that education level, marital status, and perceived level of devoutness were not related to death anxiety, and that single men experienced greater death anxiety than single women. Şenol (1989) found that education level did not affect death anxiety, while Yildiz (1998) found that marital status was not related to death anxiety. Conversely, Hökelekli (1991) conducted a study on the relationship between death-related attitudes and religious behaviors among 378 undergraduate students (aged 24-60 years) from different professions. In the study, it was observed that age was not a determinant of death anxiety, whereas there was a significant positive correlation between death-related attitudes and religious devoutness. Henrie and Hick-Patrick (1970) found that death anxiety was related to the perceived level of devoutness in a negative way, while positively related to religious suspicion, based on the data from 635 young, middle-aged, and elderly individuals. Moreover, Alvarado, Templer, Bresler, and Thomas-Dobson (1995), in their study of 200 individuals, found that those with high levels of religious beliefs and those who believed in life after death had less death anxiety.

The present study also found that women experienced greater death anxiety compared to men. The findings of previous studies are in accordance with this result (Henrie \& Hick-Patrick, 1970; Karadelioğlu, 2011; Rutledge \& Juhl, 2010; Thorson \& Powell, 1988; Yildız, 1998). In addition, death anxiety levels were found to be higher among witnesses to death (Azaiza, Ron, Shoham, \& Tinsky-Roimi, 2011; Ka-YingHui \& Fung, 2008), whereas some studies have revealed that death anxiety does not differ in terms of this variable (Cole, 1979; Tanrıdağ, 1997). In addition, it was reported that health professionals were less likely to experience death anxiety (Cooper \& Barnett, 2005; Sharma, Monsen, \& Gary, 1997), which may eventually result in a resistance to witnessing death and perceiving this as a natural part of life (Acehan \& Eker, 2013; Kara, 2002).

Based on the statistical analysis of the meaning in life scale, it was determined that the variables of age, gender, and education level differ in terms of the meaning in life and its subscales, whereas they do not differ in terms of other variables such as marital status, living with someone or living alone, witness to death, and perceived level of devoutness. However, previous studies have indicated that the meaning in life did not differ in terms of age, gender and educational status (Reker \& Fry, 2003, Scannell, Ailen, \& Burton, 2002; Yüksel, 2012). Finally, Taş (2011) found that the meaning in life significantly differed in terms of marital status, while Yarkın (2013) indicated that individuals who did not live alone and were in a relationship had more satisfaction in life. 
The present study found that the meaning in life differed in terms of the perceived level of devoutness. Topuz (2016) found in his study of 328 undergraduate students that religious consciousness (religious value and religious behavioral dimensions) and education were effective in explaining the meaning in life, but there was a negative and significant correlation between the meaning in life and religious consciousness. In this case, as the level of religious consciousness increased, the need to search for a new meaning in life decreased. Consequently, religion contributed to the attainment of the meaning in life in young adults and directed them according to normative religious information. In his work, Yllmaz (2013) focused on the importance of religious coping when solving psychological, sociological, and physiological problems, besides making recommendations on the contents and methods of religious education activities that center on such problems. In addition, Zika and Chamberlain (1992) found low levels of correlation between spirituality and the meaning in life.

The present study also determined that the witness to death variable was related to the meaning in life. In this regard, the results of previous studies support this finding. Taubman-Ben-Ar1, and Weintroub (2008), in their study of 66 nurses and 50 doctors working in pediatric oncology, found that having high optimism and high professional self-esteem as well as witnessing the death of patients influenced the relationship between the meaning in life and personal development. Häusler, Gellert, Deeken, Rapp, and Nordheim (2016) found that health professionals working with dementia patients and their supportive relatives developed more coping skills, which, in turn, improved their quality of life and reduced their levels of stress.

In sum, the present study revealed that, as the death anxiety and meaning in life subscale levels increased, the meaning in life levels decreased. One of the most important findings was that spiritual tendencies positively affected the search for meaning in life and that such tendencies were directly related to the life satisfaction of adults. According to Tekin (2016), the spiritual tendencies of individuals can help them become more aware of the positive aspects of life, while allowing them to cope with certain problems along the way. Considering the importance of spiritual tendencies in late adulthood, it is possible that spiritual-based psychological services can help individuals cope with death anxiety as well as guide them on their search for the meaning in life.

\section{References}

Acehan, G., \& Eker, F. (2013). Acil tıp hizmetleri veren sağlık personelinin ölüm kaygısı, ölüme ilişskin depresyon düzeyleri ve kullandıkları başa çıkma yolları [Levels of death anxiety, death related depression of health personnel providing emergency medical services, and their coping method]. Journal of Psychiatric Nursing, 4, 27-35.

Akın, A., \& Taş, İ. (2015). Yaşam Anlamı Ölçeği: Geçerlik ve güvenirlik çalışması [Meaning in life questionnaire: A study of validity and reliability]. Electronic Turkish Studies, 10, 27-36. 
Alvarado, K. A., Templer, D. I., Bresler, C., \& Thomas-Dobson, S. (1995). The relationship of religious variables to death depression and death anxiety. Journal of Clinical Psychology, 51(2), 202-204. http://dx.doi.org/10.1002/1097-4679(199503)

Azaiza, F., Ron, P., Shoham, M., \& Tinsky-Roimi, T. (2011). Death and dying anxiety among bereaved and nonbereaved elderly parents. Death Studies, 35, 610-624. http://dx.doi.org/10.10 80/07481187.2011.553325

Balc1, A. (2005). Sosyal bilimlerde araştırma [Research in social sciences]. Ankara, Turkey: Pegema Yayıncilik.

Blazer, J. A. (1973). The relationship between meaning in life and fear of death. Psychology: A Journal of Human Behavior, 10, 33-34.

Cole, M. A. (1979). Sex and marital status differences in death anxiety. Omega Journal of Death and Dying, 9, 139-147.

Combs, D. C. (1981). The effects of selected death education curriculum models on death anxiety and death acceptance. Death Studies, 5, 75-81.

Cooper, J., \& Barnett, M. (2005) Aspects of caring for dying patients which cause anxiety to first year student nurses. International Journal of Palliative Nursing, 11, 423-430.

Demirdağ, S., \& Kalafat, S. (2015). Yaşamın Anlamı Ölçeği (YAÖ): Türkçeye Uyarlama, Geçerlik ve Güvenirlik Çalışması [Meaning in life questionnaire (MLQ): The study of adaptation to turkish validity and reliability]. İn̈̈ü Üniversitesi Eğitim Fakültesi Dergisi, 16, 83-95.

Erikson, E. H. (1984). İnsanın sekiz çağı (T. B Üstün \& V. Şar, Trans.) [The life cycle completed]. Ankara, Turkey: Birey ve Toplum Yayınları.

Galt, C. P., \& Hayslip, B. (1998). Age differences in the level of overt and covert death anxiety. Omega, 37, 187-202.

Geçtan, E. (2005). Psikanaliz ve sonrası [Psychoanalysis and post]. İstanbul, Turkey: Metis Yayıncilik.

Geçtan, E. (1990). Varoluş ve psikiyatri [Existance and psychiatry]. İstanbul, Turkey: Metis Yayıncilik.

Häusler, A., Sánchez,A., Gellert, P., Deeken, F., Rapp, M. A., \& Nordheim, J. (2016). Perceived stress and quality of life in dementia patients and their caregiving spouses: Does dyadic coping matter? International Psychogeriatrics, 28, 1857-1866. https://doi.org/10.1017/S1041610216001046

Havighurst, R. J. (1972). Developmental tasks and education (3rd ed.) New York, NY: David McKay Company.

Henrie, J., \& Hicks Patrick, J. (1970). Religiousness, religious doubt, and death anxiety. Psychology Reports, 26, 3895-3897. https://doi.org/10.2466/PR0.1970.26.3.895

Hökelekli, H. (1991). Ölümle ilgili tutumlar ve dini davranış [Attitudes towards death and religious behaviour]. İslami Araştırmalar Dergisi, 5, 83-91.

Jung, C. G. (1997). Analitik Psikoloji [Analytical psychology: Its theory and practice]. İstanbul, Turkey: Payel Yayınc1lı.

Kalaoğlu Öztürk, Z. (2010). Yaşlı bireylerde ölüm kaygısı [Death anxiety in elderly cases] (Master's theses, Çukurova Üniversitesi, Tıp Fakültesi Ruh Sağlığı ve Hastalıkları Ana Bilim Dalı, Adana). Retrieved from https://tez.yok.gov.tr/UlusalTezMerkezi/ 
Kara, N. (2002). Yoğun bakım ünitelerinde çalışan hemşirelerin ölüme ilişkin duygu ve düşüncelerinin belirlenmesi [The feeling and thinking sign of I.C.U. nurses about death] (Master's theses, Gazi Üniversitesi, Sağlık Bilimleri Enstitüsü, Ankara). Retrieved from https:// tez.yok.gov.tr/UlusalTezMerkezi/

Karaca, F. (2000). Ölüm psikolojisi [Death psychology]. İstanbul, Turkey: Beyan Yayıncılık.

Karadelioğlu, P. (2011). Huzurevinde ve ev ortamında yaşayan yaşlıların yaşam doyumlarının ölüm kaygı düzeyine etkisi [The effect of life satisfaction old persons residing at home and at a nursing home upon the death anxiety level] (Master's theses, Haliç Üniversitesi, Sağlık Bilimleri Enstitüsü, Hemşirelik Anabilim Dal, İstanbul). Retrieved from https://tez.yok.gov.tr/UlusalTezMerkezi/

Karasar, N. (2012). Bilimsel araştırma yöntemi [Scientific research methods]. Ankara, Turkey: Nobel Yayıncilik.

Kasar, K. S., Karaman, E., Şahin, D. S., Yıldırım, Y., \& Aykar, F. Ş. (2016). Yaşıı bireylerin yaşadıkları ölüm kaygısı ile yaşam kalitesi [Lived in elderly persons relationship between between quality of life and death anxiety]. Gümüşhane Üniversitesi Sağlık Bilimleri Dergisi, 5, 48-55.

Ka-YingHui, V., \& Fung, H. H. (2008). Mortality anxiety as a function of intrinsic religiosity and perceived purpose in life. Death Studies, 33, 30-50. https://doi.org/10.1080/07481180802494099

Levinson, D. J. (1986). A conception of adult development. American Psychologist, 41, 3-13.

Levinson, D. J. (1996). The seasons of a woman’s life. New York, NY: Alfred A. Knopf.

Lyke, J. (2013). Associations among aspects of meaning in life and death anxiety in young adults. Death Studies, 37, 471-482. http://dx.doi.org/10.1080/07481187.2011.649939

Martindale, B. (1998). On ageing, dying, death and eternal life. Psychoanalytic Psychotherapy, 12, 259-270. http://dx.doi.org/10.1080/02668739800700231

Onur, B. (2000). Gelişim psikolojisi: Yetişkinlik, yaşl1lık ve ölüm (5. basım) [Developmental psychology: Adulthood, old age and death]. Ankara, Turkey: İmge Yayınları.

Prager, E. (1997). Meaning in later life: An organizing theme for gerontological curriculum design. Educational Gerontology: An International Quarterly, 23, 1-13. http://dx.doi. org/10.1080/0360127970230101

Rappaport, H., Fossler, R. L., Bross, L. S., \& Gilden, D. (1993). Future time, death anxiety, and life purpose among older adults. Death Studies, 17, 369-379.

Reker, G. T., \& Fry, P. S. (2003). Factor structure and invariance of personal meaning measures in cohorts of younger and older adults. Personality and Individual Differences, 35, 977-993.

Ross, L. M., \& Pollio, H. R. (1991). Metaphors of death: A thematic analysis of personal meanings. Omega Journal of Death and Dying, 23, 291-307.

Routledge, C., \& Juhl, J. (2010). When death thoughts lead to death fears: Mortality salience increases death anxiety for individuals who lack meaning in life. Cognition an Emotion, 24, 848-854.

Russac, R. J., Gatliff, C., Reece, M., \& Spottswood, D. (2007). Death anxiety across the adult years: An examination of age and gender effects. Death Studies, 31, 549-561.

Scannell, E., Allen, F., \& Burton, J. (2002). Meaning in life and positive and negative well being. North American Journal of Psychology, 4, 93-112.

Şenol, C. (1989). Ankara ilinde kurumlarda yaşayan yaşlılarda ölüme ilişkin kaygı ve korkular [Anxieties and fears about death in the elderly living in institutions in Ankara] (Master's theses, Ankara Üniversitesi, Sosyal Bilimler Enstitüsü, Ankara). Retrieved from https://tez.yok.gov.tr/ UlusalTezMerkezi/ 
Sezer, S. (2012). Yaşamın anlamı konusuna kuramsal ve psikometrik çalışmalar açısından bir bakış [A look at the theory and psychometric studies for the meaning of life]. Journal of Faculty of Educational Sciences, 45, 209-227.

Sezer, S., \& Saya, P. (2009). Gelişimsel açıdan ölüm kavramı [Death concept from developmental view]. Dicle University Journal of Ziya Gökalp Education Faculty, 13, 151-165.

Sharma, S., Monsen, R. B., \& Gary, B. (1997). Comparison of attitudes toward death and dying among nursing majors and other college students. Omega Journal of Death and Dying, 34, 219-232. http://dx.doi.org/10.1080/05568641.2015.1014541

Sigrist, M. J. (2015). Death and the meaning of life. Philosophical Papers, 44, 83-102. http:// dx.doi.org/10.1080/05568641.2015.1014541

Steger, M. F., Frazier, P., Oishi, S, \& Kaler, M. (2006). The meaning in life questionnaire: Assessing the presence of and search for meaning in life. Journal of Counseling Psychology, 53(1), 80-93. http://dx.doi.org/10.1037/0022-0167.53.1.80

Tanhan, F. (2007). Ölüm kaygısı ile baş etme eğitiminin ölüm kaygısı ve psikolojik iyi olma düzeyine etkisi [The effect of anxiety training on death anxiety and psychological well-being] (Master's theses, Ankara Üniversitesi, Eğitim Bilimleri Enstitüsü, Ankara). Retrieved from https://tez.yok.gov.tr/UlusalTezMerkezi/

Tanrıdağ, Ş. R. (1997). Hemşirelerin ölüm kaygıları ve genel kaygı düzeyleri arasındaki ilişkinin incelenmesi [Death anxiety of nurses and their trait anxiety]. Türk Psikolojik Danışma ve Rehberlik Dergisi, 2, 37-40.

Taş, İ. (2011). Öğretmenlerde yaşamın anlamı yaşam doyumu sosyal karşılaştırma ve iç dış kontrol odağının çeşitli değişkenler açısından incelenmesi [The search of meaning of life, life satisfaction, social comparison and internal-external locus control in terms of different variants] (Master's theses, Sakarya Üniversitesi, Sosyal Bilimler Enstitüsü, Sakarya). Retrieved from https://tez.yok.gov.tr/UlusalTezMerkezi/

Taubman-Ben-Ari, O., \& Weintroub, A. (2008) Meaning in life and personal growth among pediatric physicians and nurses. Death Studies, 32, 621-645.

Tekin, I. (2016). Manevi temelli yaklaşımla gerçekleştirilen yaşam doyumunu artırma grup çalışması [Spiritual-based approach to life satisfaction group work]. In M. Yukay-Yüksel (Ed.), Orta ve ileri yetişkinlik dönemindeki bireylere yönelik grup programları [Group programs for middle and advanced adulthood] (pp. 246-267). Ankara, Turkey: Nobel Yayınları.

Thorson, J. A., \& Powell, F. C. (1988). Elements of death anxiety and meanings of death. Journal of Clinical Psychology, 44, 691-701. http://dx.doi.org/10.1002/1097-4679(198809)

Topuz, İ. (2016). Yaşamın anlamı ve din: Gençler üzerine bir araştırma [The meaning of life and religion: A study on youth]. İslam Medeniyeti Araştırmaları Dergisi, 1, 540-560.

Ünver, S. (1938). İstanbul halkının ölüm karşısındaki duyguları [The feelings of the people of Istanbul against death]. Yeni Türk Istanbul, 6(68), 312-321.

Yalom, İ. (2001). Varoluşçu psikoterapi [Existential psychotherapy]. İstanbul, Turkey: Kabalc1 Yayıncılik.

Yarkın, E. (2013). Temel psikolojik ihtiyaçların karşılanma düzeyinin ilişki doyum ve yaşam doyum düzeyine katkısının incelenmesi [The investigation of contributon to basic psychological needs level for life and relationship satisfaction] (Master's theses, Arel Üniversitesi, Sosyal Bilimler Enstitüsü, İstanbul). Retrieved from https://tez.yok.gov.tr/UlusalTezMerkezi/ 
Yıldız, M. (1998). Dini hayat ile ölüm kaygısı arasındaki ilişki üzerine bir araştırma [A Study on the relationship between religiosity and death anxiety] (Master's theses, Dokuz Eylül Üniversitesi, Sosyal Bilimler Enstitüsü, İzmir). Retrieved from https://tez.yok.gov.tr/UlusalTezMerkezi/

Y1lmaz, M. (2013). Yaşl1lıkta manevi destek ve din eğitiminin önemi [The importance of moral support and religious education in old age]. Atatürk Üniversitesi İlahiyat Fakültesi Dergisi, 39, 241-264.

Yüksel, R. (2012). Genç yetişkinlerde yaşamın anlamı [The meaning of life on young adult]. Sakarya Üniversitesi Ĕ̈itim Fakültesi Dergisi, 2, 69-83.

Yüksel, R. (2013). Genç yetişkinlerde aşk tutumları ve yaşamın anlamı [Love attitudes of young adults, the meaning of life] (Master's theses, Sakarya Üniversitesi, Eğitim Bilimleri Enstitüsü, Sakarya). Retrieved from https://tez.yok.gov.tr/UlusalTezMerkezi/

Zika, S., \& Chamberlain, K. (1992). On the relation between meaning in life and psychological well-being. British Journal of Psychology, 83, 133-145. 